\section{Cytotoxin Associated Gene A+ Helicobacter Pylori Infection is Related with Endothelial Dysfunction in Normotensive Individuals}

\author{
Aydın Akyüz1, Rafet Mete², Mustafa Oran³, Şeref Alpsoy1, Dursun Çayan Akkoyun1, \\ Pelin Osanmaz Değirmenci ${ }^{3}$, Okan Avcı 3 \\ ${ }^{1}$ Tekirdağ Namık Kemal University Research and Training Hospital, Department of Cardiology, Tekirdağ, Turkey \\ ${ }^{2}$ Tekirdağ Namık Kemal University Research and Training Hospital, Department of Gastroenterology, Tekirdağ, Turkey \\ ${ }^{3}$ Tekirdağ Namık Kemal University Research and Training Hospital, Department of Internal Medicine, Tekirdağ, Turkey
}

\begin{abstract}
Introduction: Cytotoxin associated gene (Cag) A+ Helicobacter pylori (HP) is the most virulent HP strain, and its association with endothelial dysfunction remains unclear. Thus we investigated the effects of CagA $+\mathrm{HP}$ on endothelial dependent dilatation and its relationship with C-reactive protein (CRP) in normotensive subjects.

Patients and Methods: Sixty individuals with CagA+ HP infection were compared with 40 individuals with CagA(-) HP infection and 50 individuals with no infection in terms of flow-mediated dilatation (FMD), nonendothelium-dependent dilatation (NED) and CRP.

Results: In the $\mathrm{CagA}+$ subjects the mean percentage of FMD was $6.3 \pm 2.7$, which was significantly lower than that of the CagA- subjects $(9.8 \pm 3.3, \mathrm{p}<0.01)$ and the uninfected controls $(10.1 \pm 2.6, \mathrm{p}<0.01)$. The mean level of CRP in the CagA+ subjects was $3.9 \mathrm{mg} / \mathrm{dL}$ (range $0.1-9.8$ ), which was significantly higher than that of the CagA- subjects $(2.3 \mathrm{mg} / \mathrm{dL}$, range $0.1-5.4, \mathrm{p}=0.01)$ and the uninfected controls $(1.9 \mathrm{mg} / \mathrm{dL}$, range $0.1-5.3, \mathrm{p}<0.01)$. In the CagA+ group CRP levels were inversely correlated with FMD ( $\mathrm{r}=0.318, \mathrm{p}=0.013)$, however not with non-endotheliumdependent dilatation (NED) $(\mathrm{r}=0.216, \mathrm{p}=0.097)$.
\end{abstract}

Conclusion: Attenuated FMD and low-grade inflammation were associated with CagA+ infection, however not with $\mathrm{CagA}(-)$ infection.

Key Words: Cytotoxine associated gene A protein; Helicobacter pylori; flow-mediated dilatation

\section{Sitotoksin İlişkili A+ Genli Helicobacter Pylori Enfeksiyonu Normotansif Bireylerde Endotelyal Disfonksiyon ile İlişkilidir}

\section{ÖZET}

Giriş: Sitotoksin ilişkili A genli Helicobacter pylori (SİAGHP), en çok virülansı olan H. pylori tipidir ve halen endotelyal disfonksiyon ile ilişkisi belirsizdir. Bu nedenle biz SİAGHP'nin endotelyal bağımlı dilatasyon üzerine etkilerini ve C-reaktif protein (CRP) düzeyleri ile ilişkisini normotansif bireylerde araştırdık.

Hastalar ve Yöntem: SİAGHP enfeksiyonu olan 60 kişi, sitotoksin ilişkili A geni negatif H. pylori (SAİGNHP) enfeksiyonlu 40 kişi ve enfeksiyonu olmayan 50 kişi ile akım aracılı dilatasyon (AAD), endotele bağımlı olmayan dilatasyon (EBOD) ve CRP düzeyleri yönünden karşılaştırıldı.

Bulgular: SİAGHP'li bireylerde ortalama AAD'nin yüzdesi $(6,3 \pm 2,7)$ SİAGNHP olanlardan $(9,8 \pm 3,3, \mathrm{p}<0,01)$ ve enfekte olmayan kontrol grubundan $(10,1 \pm 2,6, \mathrm{p}<0,01)$ belirgin olarak düşüktü. CRP'nin ortalama düzeyleri SİAGHP'li bireylerde 3,9 mg/dL (0,1-9,8 aralığında), SİAGNHP olanlardan $(2,3 \mathrm{mg} / \mathrm{dL}, 0,1-5,4$ aralığında, $\mathrm{p}=0,01)$ ve enfekte olmayan kontrol grubundan $(1,9 \mathrm{mg} / \mathrm{dL}, 0,1-5,3$ aralığında, $\mathrm{p}<0,01)$ daha yüksek idi. SIAGHP'li bireylerde CRP düzeyleri AAD ile ters korelasyon gösterdi $(\mathrm{r}=0,318, \mathrm{p}=0,013)$, fakat EBOD ile bu korelasyon görülmedi.

Sonuç: Azalmış AAD ve düşük düzeyde inflamasyon SİAGHP enfeksiyonu ile ilişkilidir, ancak SİAGNHP ile ilișkili değildir.

Anahtar Kelimeler: Sitotoksin ilişkili gen A protein; Helicobacter pylori; akım aracılı dilatasyon

\section{Correspondence}

Aydın Akyüz

E-mail: ayakyuzq5@gmail.com Submitted: 08.10 .2013

Accepted : 25.10.2013

@Copyright 2014 by Koşuyolu Heart Journal - Available on-line at www.kosuyolukalpdergisi.com 


\section{INTRODUCTION}

Numerous studies have shown that elevated C-reactive protein (CRP) levels are a marker of systemic inflammation and are associated with atherosclerosis(1). Interleukin-6 (IL6), mainly produced by activated monocytes, stimulates CRP synthesis in the liver(2). Many observational studies have suggested the possibility that some infectious agents such as Helicobacter pylori (HP), Chlamydia pneumoniae, and Cytomegalovirus interact with the endothelium and provoke inflammation and atherosclerosis (3-5).

Approximately $50 \%$ of the world's population has been estimated to be infected by HP, a gram-negative spiral bacterium associated with high rates of gastric lymphoma, gastric cancer, and gastric ulcer(6). Cytotoxine associated gene seropositive $(\mathrm{CagA}+)$ HP may influence plaque formation and they are the most virulent HP strain(7). It is reportedly much more prevalent in patients with cerebral ischemia than CagA- strains ${ }^{(8)}$. There are also several reports supporting an association between $\mathrm{CagA}+\mathrm{HP}$ infection and coronary atherosclerosis, $(9,10)$ although this relationship has not been thoroughly investigated.

Endothelial dysfunction is widely regarded as the first step in the progression of atherosclerosis(11). Hypertension, smoking, dyslipidemia, and diabetes mellitus are major risk factors for atherosclerosis and mainly provoke endothelial dysfunction. Hence, we particularly aimed to determine whether there is an association between $\mathrm{Cag} \mathrm{A}+\mathrm{HP}$ infection and endothelial dysfunction in subjects without hypertension or dyslipidemia, who did not smoke or have diabetes mellitus.

\section{PATIENTS and METHODS}

\section{Subjects}

A total of 100 patients with gastric ulcer due to HP infection and 50 healthy uninfected subjects who had no gastric ulcer were enrolled from the gastroenterology clinics involved in this study. Sixty of the infected subjects had CagA + HP, 34 males and 26 females, with a mean age of $48 \pm 10$ years. Forty of them had CagAHP, 23 males and 17 females, with a mean age of $50 \pm 11$ years. The control group was comprised of 28 male and 22 female uninfected subjects, with a mean age of $49 \pm 9$ years. We measured their height, weight, systolic and diastolic blood pressure (BP), and calculated their body mass index (BMI) as $\mathrm{kg} / \mathrm{m}^{2}$. Fasting glucose, highdensity lipoprotein cholesterol (HDL-C), low-density lipoprotein cholesterol (LDL-C), triglyceride (TG), creatinine, hemoglobin, erythrocyte mean corpuscular volume (EMCV), CRP, and fibrinogen values were measured as routine laboratory analyses. Serum levels of CRP were measured by a standard nephelometry method (Cobas 311, Roche Diagnostics, Mannheim, Germany) with a sensitivity of $0.1 \mathrm{mg} / \mathrm{L}$. A commercially available enzyme linked immunosorbent assay kit (DIA.PRO Diagnostic, Bioprobes S.r.l, Milan, Italy) was used to determine serum immunoglobulin (IgG) antibodies against $\mathrm{CagA}$ antigen. CagA antibody titers $\geq 8 \mathrm{U} / \mathrm{mL}$ were deemed seropositive, in accordance with the manufacturer's instructions. All study participants underwent endoscopy (Olympus Evis Exera 160 videoendoscopes, Olympus America Inc., Melville, NY, USA). After six biopsies were collected from each patient's stomach-two from the antrum, two from the angularis incisura and two at the corpus greater curvature blind histological assessment was performed by a pathologist using a modified Gram staining protocol. Written informed consent for participation was obtained from all patients before the study, and it was approved by the relevant ethics committee.

\section{Evaluation of Endothelial Function of the Brachial Artery}

A grey scale high-resolution color Doppler ultrasound (Esaote MyLab 50, Florence, Italy) equipped with an $11 \mathrm{MHz}$ linear transducer and a functional electrocardiogram mode was used to measure brachial artery baseline and postdilatation diameter. The changes in arterial diameter in response to flow and to sublingual nitroglycerin spray $(400 \mu \mathrm{g})$ were deemed to be flow-mediated dilatation (FMD) and non-endothelium dependent dilatation (NED) respectively. Brachial artery FMD and NED were obtained with an optimal resolution of the vessel layers as previously described(12). NED vasodilatation studies were performed after FMD measurements with a resting period of 15 minutes. With a comfortable extended right arm position and simultaneous ECG recordings to obtain optimal resting longitudinal brachial artery B-mode, a linear transducer was placed immediately above the antecubital fossa and oriented perpendicular to the vessel wall. The average of three consecutive diastolic arterial diameter measurements of the frozen $\mathrm{m}$-line image were deemed to be the baseline diameter, and a pneumatic cuff was inflated to $50 \mathrm{mmHg}$ above each patient's resting systolic BP for 5 minutes and then the cuff was rapidly deflated. The average of three frozen $\mathrm{m}$-line images at 60,90 , and 120 seconds after deflation was calculated and recorded as the postdilatation diameter. The difference between the baseline and postdilatation diameters $(\Delta)$ was divided by the baseline diameter and the percentage of FMD was obtained. The visit-to-visit coefficient of variation was $3.1 \%$ for $\Delta$ diastolic diameter of the brachial artery, as determined by reexamining 20 participants 10 days after their initial examination.

\section{Statistical Analysis}

PASW Statistics 18 for Windows (SPSS Inc., Chicago, IL, USA) was used to perform all statistical analyses. The Shapiro-Wilkins normality test was used to check the distributions of continuous variables. One-way ANOVA was used when the data were normally distributed, and KruskallWallis tests were used to analyze abnormally distributed data. $\mathrm{p}<0.05$ was considered significant. The data for continuous variables are presented as mean \pm standard deviation (SD) for the parametric data, or median, minimum, and maximum (min-max) for the nonparametric data. Either Pearson's correlation test or Spearmans's rank correlation test was used to assess the relationships between FMD and NED and the other parametric or non-parametric variables including age, BMI, systolic and diastolic BP, fasting glucose, lipids, EMCV, fibrinogen and CRP. 


\section{RESULTS}

The groups did not differ significantly with regard to age, gender, BMI, systolic or diastolic BP, fasting glucose, HDL-C, LDL-C, TG, creatinine, hemoglobin, EMCV, or fibrinogen (all p values $>0.05$ ). There were significant differences in CRP levels among the three groups. The levels of CRP were significantly elevated in patients with HP as compared to controls $(\mathrm{p}<0.01)$, and were highest in the $\mathrm{CagA}+$ group. In addition, there was a significant difference between the CagA-group and the control group $(\mathrm{p}=0.04)$ (Table 1$)$.

While baseline diameter of the brachial artery and its response to nitroglycerin did not differ significantly among the three groups, comparisons of their percentage FMD values showed significant differences between the CagA+ group (6.3 \pm 2.7$)$ and the CagAgroup $(9.8 \pm 3.3)(p<0.01)$ and between the CagA+ group and the control group $(10.1 \pm 2.6)(\mathrm{p}<0.01)$, but the CagA- group did not differ significantly from the control group in this respect (Table 2).

Neither the FMD nor the NED were significantly correlated with age, BMI, systolic or diastolic BP, fasting glucose, serum lipids, hemoglobin, EMCV, or fibrinogen. Serum CRP levels were significantly inversely correlated with FMD ( $\mathrm{r}=0.318$, $\mathrm{p}=0.013)$ but not with NED $(\mathrm{r}=0.216, \mathrm{p}=0.097)$ in the CagA+ group (Figures 1,2). No significant correlation was evident between CRP and FMD in the CagA- group or the control group. In addition, there was no significant correlation between CRP and fibrinogen levels in any of the groups (Table 3).

\section{DISCUSSION}

No study thus far has documented whether CagA+ HP strains have a greater effect on endothelial function than CagA- HP strains. In this study, we detected higher levels of serum CRP and attenuated FMD in normotensive subjects who were seropositive for CagA+ HP than in CagA- HP infected subjects and healthy subjects. Notably, we eliminated effects arising from diabetes mellitus, dyslipidemia, or smoking by excluding any subjects with those conditions from the study. Neither NED, that reflects vascular smooth muscle function, nor fibrinogen levels differed significantly among the three groups. In additon, there was no relationship between NED and CRP levels.

\begin{tabular}{|c|c|c|c|c|}
\hline Variable & $\begin{array}{l}\text { CagA }+ \text { HP } \\
\text { group } \\
\mathbf{n}=\mathbf{6 0}\end{array}$ & $\begin{array}{l}\text { CagA- HP } \\
\text { group } \\
\mathbf{n}=\mathbf{4 0}\end{array}$ & $\begin{array}{l}\text { Control group } \\
\mathbf{n}=\mathbf{5 0}\end{array}$ & $\begin{array}{l}p \\
\text { value }\end{array}$ \\
\hline Gender, male & $34(56.6)$ & $23(57.5)$ & $28(56)$ & $0.848^{*}$ \\
\hline BMI, $\mathrm{kg} / \mathrm{m}^{2}$ & $26.8 \pm 2.7$ & $27 \pm 3.2$ & $25.7 \pm 3.6$ & $0.098^{*}$ \\
\hline Diastolic BP, mmHg & $79 \pm 6$ & $78 \pm 5$ & $74 \pm 7$ & $0.558^{*}$ \\
\hline Fasting glucose, $\mathrm{mg} / \mathrm{dL}$ & $82(54-106)$ & $80(58-99)$ & $77(57-104)$ & $0.442 \dagger$ \\
\hline HDL-C, mg/dL & $51 \pm 8.5$ & $53 \pm 9$ & $50.5 \pm 8.7$ & $0.604 *$ \\
\hline LDL-C, mg/dL & $129(55-157)$ & $128(39-155)$ & $124(49-152)$ & $0.567^{\dagger}$ \\
\hline Triglyceride, $\mathrm{mg} / \mathrm{dL}$ & $122(59-149)$ & $124(61-147)$ & $118(48-148)$ & $0.459^{\dagger}$ \\
\hline C-reactive protein, $\mathrm{mg} / \mathrm{dL}$ & $3.9(0.1-9.8)^{\mathrm{a}}$ & $2.3(0.1-5.4)^{\mathrm{b}}$ & $1.9(0.1-5.3)^{\mathrm{c}}$ & $<0.01 \dagger$ \\
\hline Fibrinogen, $\mathrm{mg} / \mathrm{dL}$ & $313 \pm 69$ & $299 \pm 74$ & $292 \pm 59$ & $0.086^{*}$ \\
\hline
\end{tabular}

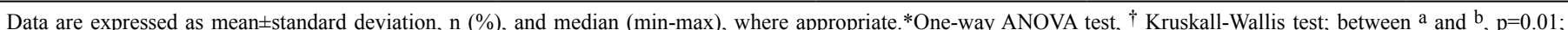

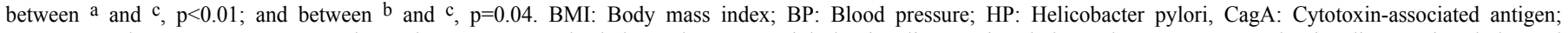

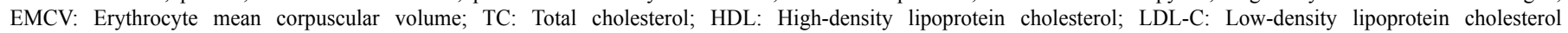

Table 2. Brachial artery parameters in all groups

\begin{tabular}{|c|c|c|c|c|}
\hline & $\begin{array}{l}\text { CagA+ HP } \\
\text { group }\end{array}$ & $\begin{array}{l}\text { CagA- HP } \\
\text { group }\end{array}$ & Control group & p value* \\
\hline Baseline vessel diameter, $\mathrm{mm}$ & $3.3 \pm 0.44$ & $3.5 \pm 0.45$ & $3.3 \pm 0.53$ & 0.115 \\
\hline Non-endothelium-dependent, \% & $12.3 \pm 2.4$ & $12.2 \pm 2.9$ & $13 \pm 2.7$ & 0.246 \\
\hline
\end{tabular}


Our findings support the suggestion that low-grade chronic inlammation is associated with endothelial dysfunction and suggest that CagA + seropositive HP infected patients may be at higher risk of cardiovascular disease.

The evaluation of FMD, an index of vasomotor function, is a noninvasive and reliable method to detect endothelial dysfunction by measuring brachial artery diameter changes in response to hyperemia. There is a close relationship between endothelial dysfunction in the forearm and coronary endothelial dysfunction(13).

It is well known that low-grade persistent increased CRP levels reflect a chronic inflammatory state, and are associated with endothelial dysfunction and atherosclerosis $(1,14,15)$.
Our study suggests that the CagA antigen is associated with elevated CRP levels, and chronic infection with CagA+ HP strains may directly or indirectly provoke a continuing systemic and vascular inflammatory response and endothelial dysfunction. However, further studies are required to explain the relationship between CagA antigen and cytokine release by monocytes.

Some studies have shown that atherosclerosis is associated with HP infection, $(16,17)$ and there are several studies showing a relationship between $\mathrm{CagA}+\mathrm{HP}$ strains and atherosclerosis, which is increasingly recognized as an inflammatory disease $(18,19)$. The associations between HP infection and endothelial dysfunction and systemic inflammation in healthy

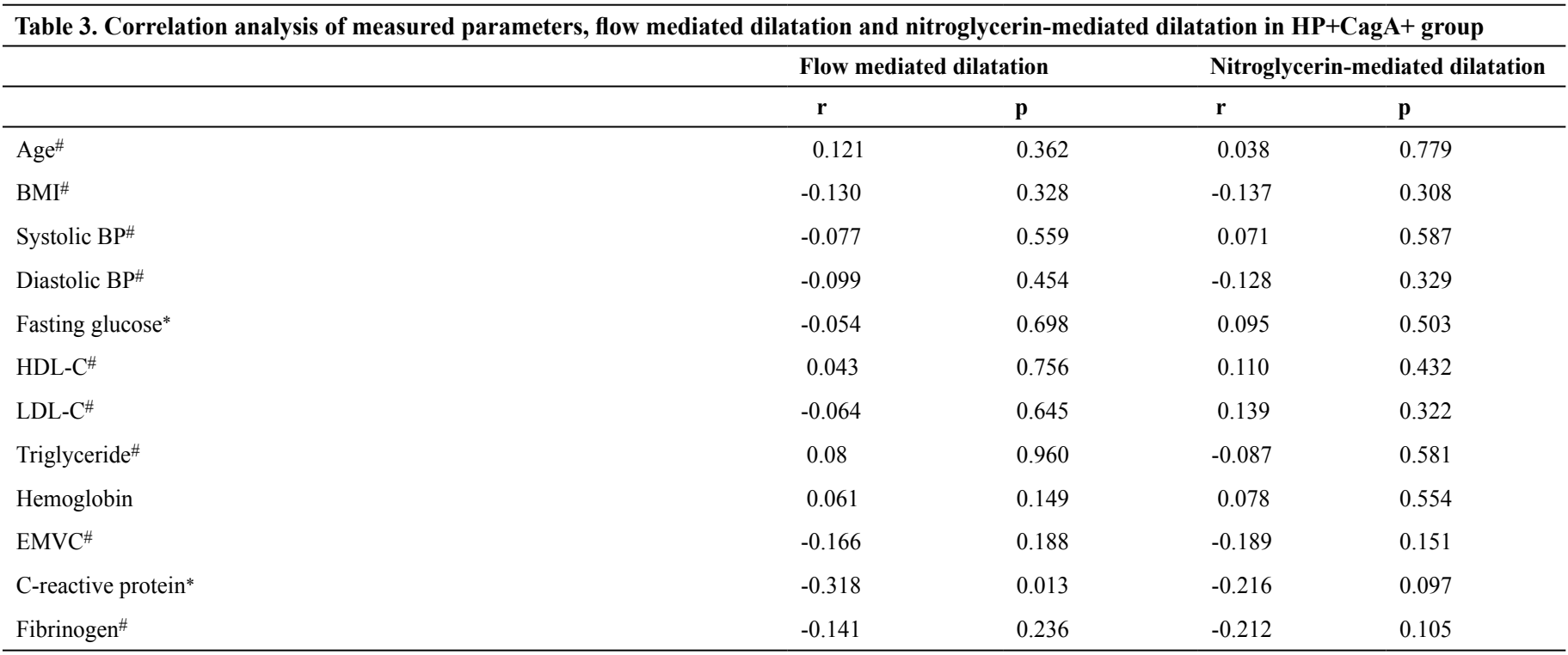

${ }^{*}$ Spearmans'rank correlation analysis, \#Pearson correlation analysis BMI: Body mass index; BP: Blood pressure; HP: Helicobacter pylori, CagA: Cytotoxin-associated antigen; EMCV: Erythrocyte mean corpuscular volume; HDL: High-density lipoprotein cholesterol; LDL-C: Low-density lipoprotein cholesterol

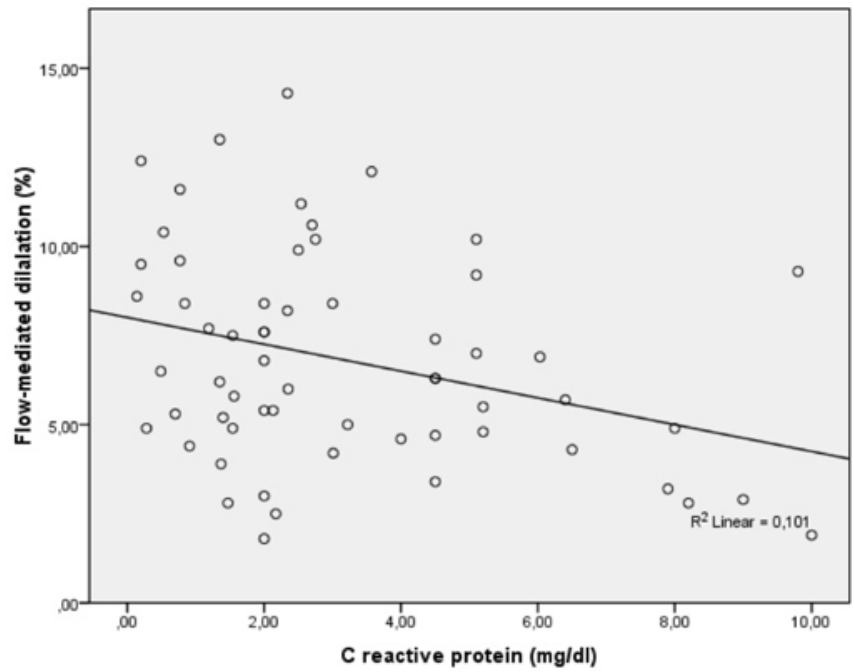

Figure 1. A negative linear relation between serum C-reactive protein and flow-mediated dilatation is shown on scatter diagram $(\mathrm{r}=0.318, \mathrm{p}=0.013)$

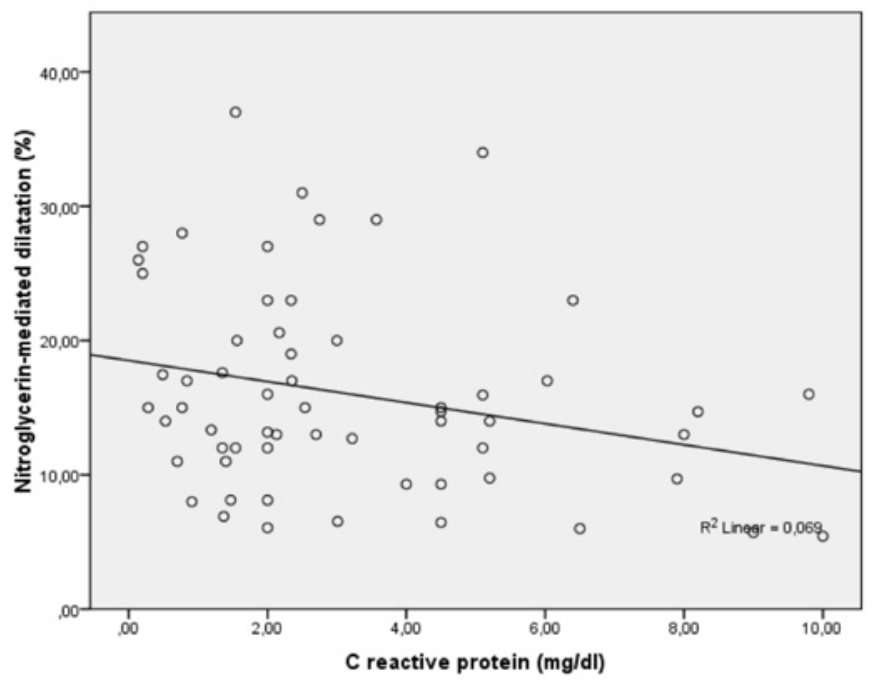

Figure 2. No correlation was shown between non-endothelium dependent dilatation and flow-mediated dilatation on scatter diagram $(\mathrm{r}=0.216, \mathrm{p}=0.097)$ 
subjects were reported by Oshima et al.(20) but they did not investigate the influence of CagA + HP strains on endothelial function. Although the exact mechanism of augmented atherosclerosis in $\mathrm{CagA}+\mathrm{HP}$ infected individuals is not well understood, some studies have shown the presence of molecular mimicry between the HP CagA antigen and vascular wall antigens in atherosclerotic plaques; it was suggested in those reports that autoimmune mechanisms may explain the relationship between HP and atherosclerosis $(2,19)$. In addition, a study involving bovine aortic endothelial cells showed that CagA antigen induces endothelial injury, and reduces endothelial nitric oxide, which plays a key role in vasodilatory responses(21).

It is well known that cardiovascular risk factors such as hypertension, diabetes, smoking, and dyslipidemia alter endothelium-dependent vasodilatation(22-24). Some authors have postulated that HP infection augments atherosclerosis by modyfying and increasing serum lipids $(7,25)$. We particularly excluded hypertension, diabetes, smoking, and dyslipidemia from the study to better determine the effects of CagA + HP on endothelial function.

One limitation of this study was its sample size. Secondly, HP may contribute to the malabsorption of folate, vitamin B6, and vitamin B12, and it may lead to hyperhomocysteinemia(26), which may alter endothelial function(27). However, there are some inconsistent reports in this respect; Yoshino et al.(28) has claimed that HP infection is not associated with hyperhomocysteinemia. We did not measure serum homocysteine levels, but EMCV levels were similar in all groups, which may predominantly reflect normal vitamin B12 levels and, in part at least, homocysteine levels.

In conclusion, we showed a relationship between lowgrade chronic inflammation and infection with $\mathrm{CagA}+$ $\mathrm{HP}$, in conjunction with attenuated endothelial function, in normotensive subjects without diabetes or dyslipidemia, that did not smoke. Because low-grade systemic persistent inflammation induced by $\mathrm{CagA}+\mathrm{HP}$ infection is amenable to treatment, it might warrant consideration in the context of decelerating the progression of atherosclerosis in clinical practice. However, larger clinical studies are needed to explain the pathophysiologic associations between CagA antigen and increased low grade inflammation.

\section{CONFLICT of INTEREST}

The authors reported no conflict of interest related to this article.

\section{REFERENCES}

1. Cesari M, Penninx BW, Newman AB, Kritchevsky SB, Nicklas $\mathrm{BJ}$, Sutton-Tyrrell K, et al. Inflammatory markers and onset of cardiovascular events: results from the Health $\mathrm{ABC}$ study. Circulation 2003;108:2317-22.

2. Morrone G, Ciliberto G, Oliviero S. Recombinant interleukin 6 regulates the transcriptional activation of a set of human acute phase genes. J Biol Chem 1988;263:12554-8.
3. Franceschi F, Sepulveda AR, Gasbarrini A, Pola P, Silveri NG, Gasbarrini $\mathrm{G}$, et al. Cross-reactivity of anti-CagA antibodies with vascular wall antigens: possible pathogenic link between Helicobacter pylori infection and atherosclerosis. Circulation 2002;106:430-4.

4. Gattone $\mathrm{M}$, Iacoviello $\mathrm{L}$, Colombo $\mathrm{M}$, Castelnuovo $\mathrm{AD}$, Soffiantino F, Gramoni A, et al. Chlamydia pneumoniae and cytomegalovirus seropositivity, inflammatory markers, and the risk of myocardial infarction at a young age. Am Heart J 2001;142:633-40.

5. Keller TT, Mairuhu AT, De Kruif MD, Klein SK, Gerdes VE, Ten Cate $\mathrm{H}$, et al. Infections and endothelial cells. Cardiovasc Res 2003;60:408.

6. Brown LM. Helicobacter pylori: epidemiology and routes of transmission. Epidemiol Rev 2000;22:283-97.

7. Huang B, Chen Y, Xie Q, Lin G, Wu Y, Feng Y, et al. CagA-positive Helicobacter pylori strains enhanced coronary atherosclerosis by increasing serum OxLDL and HsCRP in patients with coronary heart disease. Dig Dis Sci 2011;56:109-14.

8. Pasceri V, Patti G, Cammarota G, Pristipino C, Richichi G, Di Sciascio G. Virulent strains of Helicobacter pylori and vascular diseases: a metaanalysis. Am Heart J 2006;151:1215-22.

9. Jafarzadeh A, Esmaeeli-Nadimi A, Nemati M, Tahmasbi M, Ahmadi P. Serum concentrations of Helicobacter pylori IgG and the virulence factor CagA in patients with ischaemic heart disease. East Mediterr Health $\mathrm{J}$ 2010;16:39-44.

10. Niccoli G, Franceschi F, Cosentino N, Giupponi B, De Marco G, Merra G, et al. Coronary atherosclerotic burden in patients with infection by CagApositive strains of Helicobacter pylori. Coron Artery Dis 2010;21:217-21.

11. Vanhoutte PM. Endothelial dysfunction: the first step toward coronary arteriosclerosis. Circ J 2009;73:595-601.

12. Urbina EM, Williams RV, Alpert BS, Collins RT, Daniels SR, Hayman L, et al. American Heart Association Atherosclerosis, Hypertension, and Obesity in Youth Committee of the Council on Cardiovascular Disease in the Young. Noninvasive assessment of subclinical atherosclerosis in children and adolescents: recommendations for standard assessment for clinical research: a scientific statement from the American Heart Association. Hypertension 2009;54:919-50.

13. Anderson TJ, Uehata A, Gerhard MD, Meredith IT, Knab S, Delagrange $\mathrm{D}$, et al. Close relation of endothelial function in the human coronary and peripheral circulations. J Am Coll Cardiol 1995;26:1235-41.

14. Yudkin JS, Stehouwer CD, Emeis JJ, Coppack SW. C-reactive protein in healthy subjects: associations with obesity, insulin resistance, and endothelial dysfunction: a potential role for cytokines originating from adipose tissue? Arterioscler Thromb Vasc Biol 1999;19:972-8.

15. Möhlenkamp S, Lehmann N, Moebus S, Schmermund A, Dragano N, Stang A, et al. Heinz Nixdorf Recall Study Investigators. Quantification of coronary atherosclerosis and inflammation to predict coronary events and all-cause mortality. J Am Coll Cardiol 2011;57:1455-64.

16. Jin SW, Her SH, Lee JM, Yoon HJ, Moon SJ, Kim PJ, et al. The association between current Helicobacter pylori infection and coronary artery disease. Korean J Intern Med 2007;22:152-6.

17. Strachan DP, Mendall MA, Carrington D, Butland BK, Yarnell JW, Sweetnam PM, et al. Relation of Helicobacter pylori infection to 13-year mortality and incident ischemic heart disease in the caerphilly prospective heart disease study. Circulation 1998;98:1286-90.

18. Pasceri V, Cammarota G, Patti G, Cuoco L, Gasbarrini A, Grillo RL, et al. Association of virulent Helicobacter pylori strains with ischemic heart disease. Circulation 1998;97:1675-9.

19. Rožanković PB, Huzjan AL, Cupić H, Benčić IJ, Bašić S, Demarin V. Influence of CagA-positive Helicobacter pylori strains on atherosclerotic carotid disease. J Neurol 2011;258:753-61.

20. Oshima T, Ozono R, Yano Y, Oishi Y, Teragawa H, Higashi Y, et al Association of Helicobacter pylori infection with systemic inflammation and endothelial dysfunction in healthy male subjects. J Am Coll Cardiol 2005;45:1219-22.

21. Tobin NP, Henehan GT, Murphy RP, Atherton JC, Guinan AF, Kerrigan SW, et al. Helicobacter pylori-induced inhibition of vascular endothelial cell functions: a role for VacA-dependent nitric oxide reduction. Am J Physiol Heart Circ Physiol 2008;295:H1403-13.

22. Park JB, Charbonneau F, Schiffrin EL. Correlation of endothelial function in large and small arteries in human essential hypertension. J Hypertens $2001 ; 19: 415-20$ 
23. Hink U, Li H, Mollnau H, Oelze M, Matheis E, Hartmann M, et al. Mechanisms underlying endothelial dysfunction in diabetes mellitus. Circ Res 2001;88:E14-2.

24. Heitzer T, Ylä-Herttuala S, Luoma J, Kurz S, Münzel T, Just H, et al. Cigarette smoking potentiates endothelial dysfunction of forearm resistance vessels in patients with hypercholesterolemia. Role of oxidized LDL. Circulation 1996;93:1346-53.

25. Chimienti G, Russo F, Lamanuzzi BL, Nardulli M, Messa C, Di Leo A, et al. Helicobacter pylori is associated with modified lipid profile: impact on Lipoprotein(a). Clin Biochem 2003;36:359-65.
26. Sung JJ, Sanderson JE. Hyperhomocysteinaemia, Helicobacter pylori, and coronary heart disease. Heart 1996;76:305-7.

27. Al-Shaer MH, Raghuveer G, Browning R, Sinkey CA, Chenard C, Stumbo P, et al. Effect of hyperhomocysteinemia induced by methionine administration on flow-mediated dilatation of the brachial artery in healthy subjects. Am J Cardiol 2005;95:428-30.

28. Yoshino N, Adachi K, Takashima T, Miyaoka Y, Yuki T, Ishihara S, et al. Helicobacter pylori infection does not affect the serum level of homocysteine. Am J Gastroenterol 2002;97:2927-8. 